\title{
Inspirative Geology - the Influence of Natural Geological Formations and Patterns on Contemporary Landscape Design
}

\author{
Nawarah Al Basha, Anna Eplényi PhD, Gábor Sándor \\ Szent István University, Faculty of Landscape Architecture and Urban Design, Hungary
}

\begin{abstract}
Throughout the history of landscape design, we have witnessed many examples where natural features were used as symbolic elements of manmade landscapes and gardens. This influence of landscape geology had its impact on contemporary landscape architecture, resulting in diverse and innovative applications, which are the main topic of our discussion.

The article is intended to demonstrate the trend of drawing inspiration from natural landscape features in contemporary landscape architecture in a new and complex way, focusing particularly on the influence of geology, geomorphology and tectonics.

A study was conducted on twelve available, published contemporary landscape projects from the last two decades analysing the imitation of nature in the designs, with photo documentation and description. The aim is to identify how 'native geology' can influence today's landscape architecture, which formations are inspirative, where and how they are integrated to the contemporary artistic design.

Furthermore, in order to develop a complex understanding on how these references applied to the sites enhance the experience of the space. The selected projects are compared according to pairs of contrasting qualities that are related to measurable characteristics of a space. This will finally lead to identifying some common trends of today's landscape architecture in applying this geology-inspired design approach.
\end{abstract}

Keywords: geological formations, geological patterns, geomorphological influence, mimicry, abstraction

\section{Introduction}

The masterpieces in garden history and of landscape design are usually inspired by landscapes, landforms and natural phenomenon: such as coasts, riverscapes, caves, mountains, rocks or special vegetation. There is an important link between the sitespecific reality of natural landscapes and the ways of their abstraction on the designer's desk. How a particular location, a real site can influence the landscape architect's aims and design concept? How many types of transformations can the original phenomenon have? In this article, we only focus on a particular source of this transformation, the influence of geology, geomorphology and tectonics. Searching, describing and comparing contemporary design projects, we aim to develop an understanding on how 'native geology' can influence today's landscape architecture, which forms are inspirative, where and why they are applied, and how the original geomorphology is applied.

\section{Geology and garden art - Historical overview (Figure 1)}

There is a great difference between the Eastern and Western approach in applying natural landforms into garden design: the Western approach (originating from the Bible) says: the "Eden Garden" is a separated, fenced, sheltered part of landscape; saved from dangerous, outer rural life. These gardens were associated with a maintained, well-kept, artistic and friendly nature. Therefore, the garden, the humanized nature has always been more appreciated than the wild, rustic phenomena. On the contrary, at the east (Chinese, Japanese art), where amazing vertical hilltops, narrow valleys and large rocks were the birthplaces of kami and chi energy, the garden is only a small, reflective copy of the great, boundless, impressive nature.

Therefore, the adaptations of real sites to garden art took a very different symbolic route in European garden history. In Japanese garden art, the abstraction of geomorphological sites already appeared in Kamakura period: the dry stone waterfall-setting (kare-taki) of Saiho-ji or Tenryu-ji remind us the natural waterfall structures of Japanese countryside, as well as the pebble stone dry streams (kare-nagare). The imitation of Oigawa River at Koishikawa Korakuen Garden (Tokyo) is a delicate example: the shoal riverbed with random stones imitates the original low tides. When looking at the two flat upstanding stones in Daisen-in (Daitoku-ji, Kyoto), we can clearly recognize the Mt. Horai from the silhouette, surface and greyish color.

In Chinese garden art, we are aware that the 40 Scenes of Yuangmingyuan were also strongly influenced by Southern Chinese landscapes that Emperor Qianlong personally visited. Not only stones, but also plants and houses were carried to Beijing for recreating the character of those sites as accurately as possible! 


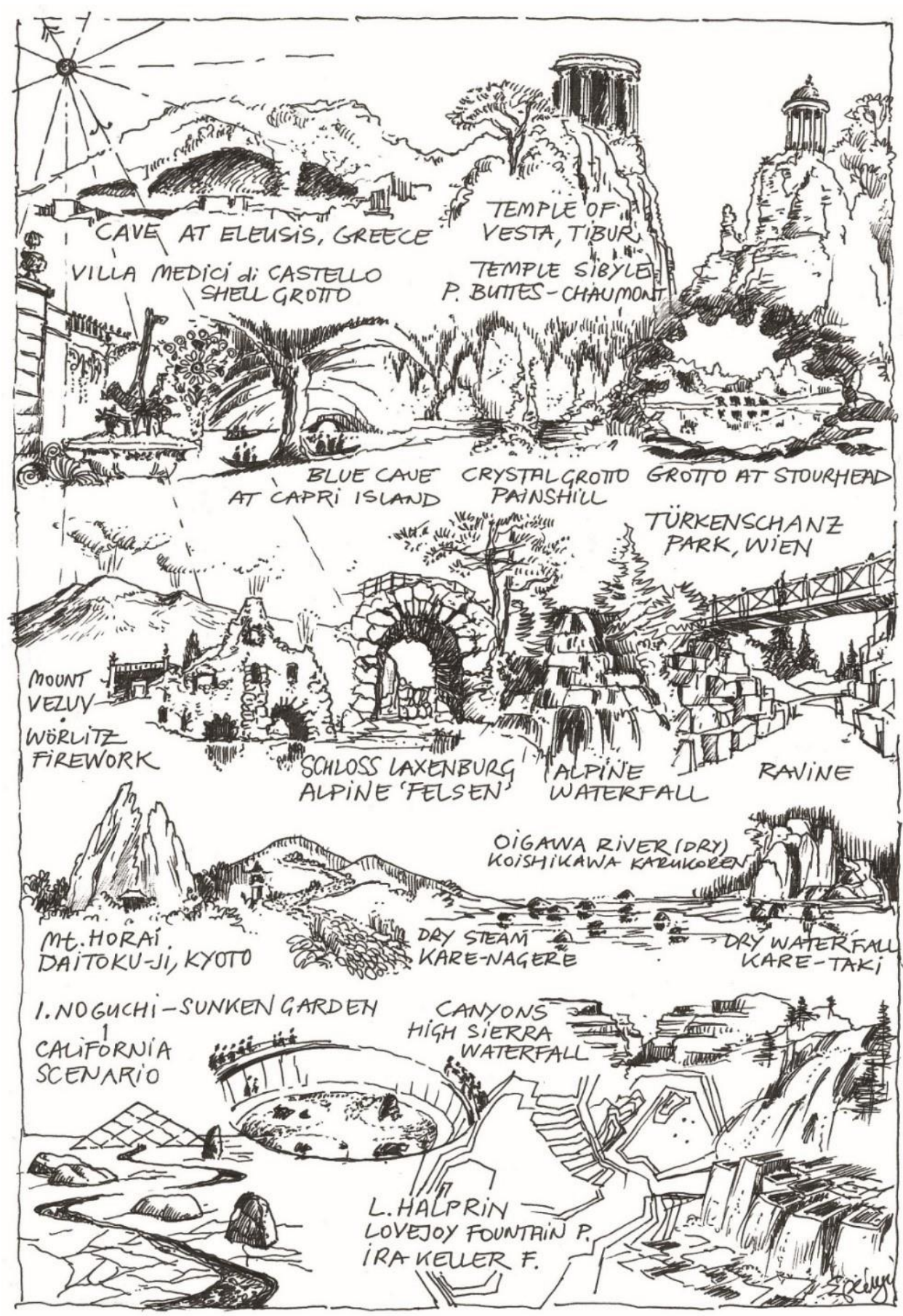

Fig. 1. Features from garden history inspired by geology [drawing by Anna Eplényi]

In Europe, it was the Ancient Greeks who emphasized designating sacred locations in the rural landscape, and furnished them by adding some altars, natural pools, and preserving old trees around (Cave at Eleusis: Persephoné's passage to the underworld). The picturesque Temple of Vesta at Tibur cliffs later inspired many monopteroi on rocks in classical parklands (Park Buttes-Chaumont, Eisenstadt- Esterházy Park).

In the Renaissance and Baroque garden arts, the rustic naturalness was usually symbolized with a grotto. The word 'grotto' comes from the Greek word kruptos, meaning 'hidden'. It invokes depth, darkness, silence and mystery. Although we can hardly identify any real cave that served as a source of inspiration, the material was taken from crystal caves and placed accurately like stalactites with shells, or flinths, tufas and peddle stones. "The Crystal Grotto at Painshill is a magical, naturalistic cave with shimmering, bubbling water, rough rock and stalactites covered in sparkling crystals. The grottoes Ch. Hamilton saw in European gardens had water, rough rocks but were more architectural as structures. He may have seen some 
of the natural caves along the Roman coastline of Italy (Capri Blue Cave)." A special feature here is that the light-reflections are coming from underwater.

On the Continent, we can find Europe's largest and oldest artificial volcano in Wörlitz Park. It is a reference to Vesuvius what Leopold III, Duke of Anhalt-Dessau personally visited. He was inspired to create his 'model Vesuvius' according to the volcanological researches of Sir W. Hamilton, British envoy, whom he had met in Italy in 1766. That is how the red Villa by the rock was dedicated to him. Grottos were easy to combine with other landforms such as hilltops: (Eisenstadt), caves (Tata Hell grotto), retaining walls (Villa Medici di Castello) or lakeshores (Stourhead). These combinations could have various narrative stories.

An exact reference to the Alps can be found in Laxenburg Schlossgarten (Vienna, 1800) where great stones are piled up to formulate dramatic, underworld spaces, caves, bridges and lookout spots. In the Türkenschanzpark, upon Vienna hills, waterfalls and ravines with a hanging bridge combined with pines and dark conifers also remind us of the Alpine landscape character.

F. Steele used fine grading and sophisticated references to local landscape. Close to Maine coastal shoreline lays the Camden Library Amphiteather (1928). In addition to the birch planting, large rocks were incorporated into the terraces to soften the rigidity of the regular curves and to evoke the presence of the nearby dramatic coastal ledges, serving both aesthetic and spiritual purposes. The traditional horseshoe form is combined with a modern touch of the rocks, creating ageless harmony.

The sculptor, I. Noguchi used his Japanese 'touch' to realise abstract terrain visions: the Sunken Garden (1964) is a sdepressed brick-lined water garden, where the main features are boulders, which Noguchi collected from Kyoto's Uji River. The California Scenario (1980) is a 1.6-acre public sculpture garden, created as a series of landscapes within a landscape: Water Source/ Water Use/ The Desert Land/ The Forest Walk/ Land Use and Energy Fountain are distinct schemes that symbolise characteristics inherent to the Californian landscape. It is both a metaphorical garden and a minimalist theatrical installation - a story made by so many type of real rocks native to the desert!

L. Halprin was also inspired by landforms. Instead of minimalism, he used the dynamics of runoff waters, the great American canyons and waterfalls as sources of inspiration. The stratigraphy of the canyons (=order of geological layers) are reflected in Lovejoy Fountain Plaza (Portland, 1960) by the structure, layout and fall of the terrain-levels throughout the plaza. The stepping stones in the pool and the narrow, torrential ravine are also abstractions of these geomorphological features. The Ira Keller Fountain (Portland, 1970) has stronger vertical and acoustic power: "this new type of people's park, where nature is abstracted with a geometric naturalism, was based on Halprin's studies of the High Sierra's spring cascades."

Some of the postmodern public spaces have also narrative geomorphological references, such as the elevated, Italy-shaped terrain-cascade by $\mathrm{Ch}$. Moore in Piazza di Italia (1978) or A. Isozaki's Tsukuba Centre canyon with the Daphne tree (1979), the Canyoneaustrate waterfall of artist G. Singer in Park Bercy (1986), or the giant, surrealistic water ripples and roars of Park Diderot by A. Provost (1992).

To sum up this historical review, we can say that there has always been a reference to nature, but until the 20th century, they were rather one-to-one, real copies of the sites. The use of hints, abstractions, minimalist references or evocations appeared only in Japanese garden art or in the last century.

\section{Representations of geology in contemporary landscape design}

This part reviews 12 contemporary design projects from the last two decades, which demonstrate an influence of geological patterns and formations in their design concepts. The projects were chosen in an attempt to show the variation of interpretations of this influence, by way of example, not exhaustive enumeration. They are listed in ascending chronological order with a brief description of the design as well as the geological/geomorphological feature, which the design takes the inspiration from.

Federal Courthouse Plaza, 1997

Minneapolis, Minnesota, U.S

Urban Public Space

Designer: Martha Schwartz

Design_ The plaza is designed in front of a new federal courthouse to accommodate both civic and individual activities, with the aim of creating an urban plaza with its own identity. The entire surface is designed with a linear paving pattern of white stripes of concrete, with drop-shaped grass mounds juxtaposed at 30 degrees angle.

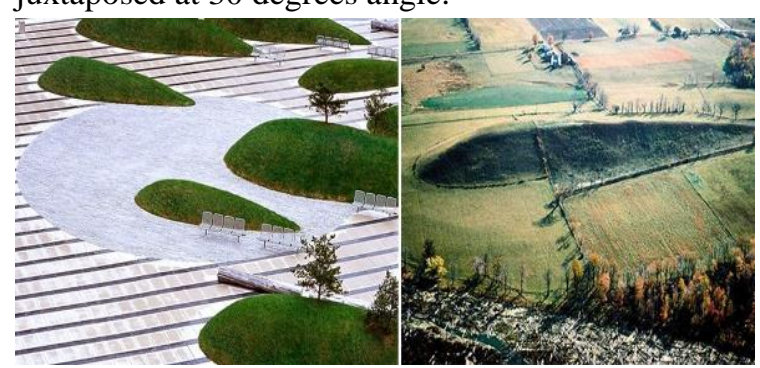

Fig. 2. The artificial drumlins in the plaza compared to the form of a natural drumlin. [Photo (C Left: msp.world, Right: geocaching.com ID-GC82N03] 
The elliptical mounds are soil planting-piles, as the plaza is designed on top of a parking garage, and intended to evoke a memory of geological and cultural forms as well. They suggest a field of glacial drumlins [5].

Geomorphological Influence_ A drumlin is an oval or elongated hill formed as moving glaciers deposited tills of clay, sand, silt and gravel on outcroppings in their paths. Drumlins can be found in clusters called an "egg basket" numbering in thousands. Drumlin fields were formed in the late Wisconsin glacial stage.

The imitation of drumlins communicates a reference to Minnesota's natural and cultural landscape history, which addresses the collective memory of the visitors and leaves them with an emotional imprint. Although the design suffices to using the explicit three-dimensional elliptical form of drumlins without other elements contributing to the attempt of creating a reference to a certain environment, the effect is still quite strong and dominant over the space, due to the intensive number of mounds and their functional role in orienting movement throughout the plaza.

\section{Interpolis Headquarters Garden, 1998}

Tilburg, the Netherlands, Public Garden

Designer: West 8

Design_ The garden forms a calm and introverted world designed for relaxation, relatively separated from its surroundings but freely accessible by the public. The design is strongly influenced by natural geological features. The grass surface has a pattern of tectonic shifts. An elongated plateau of large slate slabs is laid out against the building, imitating a natural slate landscape, and is topped by a punctuating layer of a magnolia grove spread across its surface [6].

Geological Influence_Slate is a fine grained, foliated, homogeneous metamorphic rock composed of clay or volcanic ash through low-grade regional metamorphism. Slates display a property called fissility, forming smooth flat sheets of stone.

The massive layer of Norwegian slate, which is known as one of the local roofing and flooring materials in the Netherlands, forms a bleak landscape against the building, creating a counterweight to the heavyweight architecture.

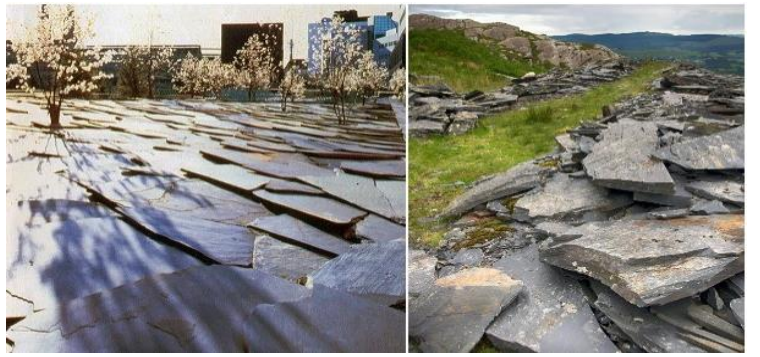

Fig. 3. The garden's plateau of slate slabs compared to a natural slate landscape [Photo $($ Left: west8.com, Right: alamy.com ID-KK7T85]
The interpretation of tectonic shifts with the grass surface is two-dimensional and serves a simple decorative role, but still creates a changing sense of perspective in the garden.

\section{Teardrop Park, 2004}

Manhattan, NYC, U.S, Public Park

Designer: Michael Van Valkenburgh Ass.

Design_ The park displays a distinctive spatial structure with components like a marsh, an ice-water wall and water play rocks, which mimic natural forms of the Hudson River Valley, providing an experience of natural environment for the citizens and kids. A distinctive reinterpretation of New York geology is the ice-water wall that is constructed with stacked Alcove bluestones to resemble a natural stratum [7].

Geological Influence_A stratum is a layer of sedimentary rock or soil, or igneous rock that was formed at the Earth's surface, with internally consistent characteristics that distinguish it from other layers. It appears with parallel layers known as strata. The term bluestone is derived from a deep blue-colored sandstone first found in Ulster County, New York, known for its durability and color [4].

Another manifestation of the Valley's environment is designed as an area for creative playing. Water play rocks create functional elements for interaction, indicating a geomorphological influence of the Hudson River rocks.

The project imitates the natural environment of the Valley by different means: intricate textures, scale differences and choreographed views, providing the experience of nature play in the city. The elements used to create that imitation are mostly $3 \mathrm{D}$ formations that could be easily assigned with functions, while generating the spatial structure of the park.

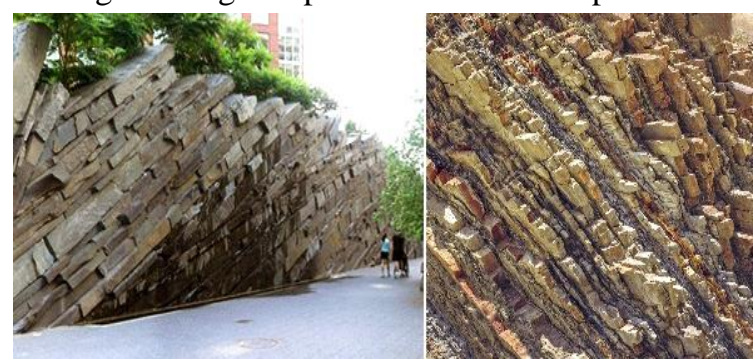

Fig. 4. The ice water wall compared to a rock strata closeup. [Photo $@$ Left: MVVA, Right: stock.adobe.com ID-156885999]



Fig. 5. The water play rocks compared to rocks on the bank of the Hudson Rive [Photo $\bigcirc$ Left: MVVA, Right: shutterstock.com ID-294723539] 


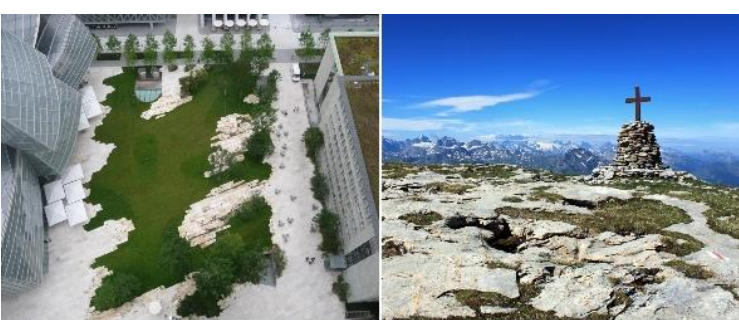

Fig. 6. The representation of karst in the project compared to its appearance on the summit of the Silberen plateau.

[Photo $\mathrm{C}$ Left: VOGT, Right: Uwelino / Wikimedia Commons]

\section{The Green, 2010}

Novartis Campus,Basel, Switzerland

Hybrid of square and park

Designer: VOGT Landscape Architects

Design_ The Green is intended as an entree for the surrounding buildings and meeting place for persons from the entire campus. The design refers to distinctive elements of karst landscape of Silberen, and reinterprets them in the context of the urban environment. The result of this adaptation is an open space: green in its center (forb-rich lawn), light-colored on its brinks (limestoneflagstones) [8].

Geological Influence_ Karst is a topography formed by the dissolution of soluble rocks. In the case of eroded limestone, flat barren landscapes are formed, perforated by furrows and holes.

The Green presents subtle discrepancies like the garden plants or high ash trees, which cannot be found in karst, indicating that the influence of karst landscape is achieved by geological mimesis. The simple design concept of a two-dimensional phenomenon covering the entire surface of the space was utilized effectively in dividing the space and creating a reference to a certain environment. The design looks like a carpet taken from the landscape wtith sensitive tactile impressions.

\section{The City Dune - SEB Bank, 2010}

Copenhagen, Denmark, Public Urban Space Designer: SLA

Design _ The City Dune is an artificial terrain that rises from street level to the second floor level, covering the bank's parking garage. It is inspired by natural processes and emulates the folding movement of the sand dunes of Northern Denmark and the snow dunes of the Scandinavian Winter. The design of the terrain handles drainage, accessibility, lighting, plantation and offers a variety of routes for different users, creating an everchanging urban space [9].

Geomorphological Influence_ The dunes in the north part of Denmark are called shoreline dunes. They were formed by the aeolian processes and made up of sand. Dried sand on the banks was accumulated by wind from sea alongshore. Shoreline dunes may stand alone or be clustered.

The abstraction of folding movement of the dunes provided the answer to functional and

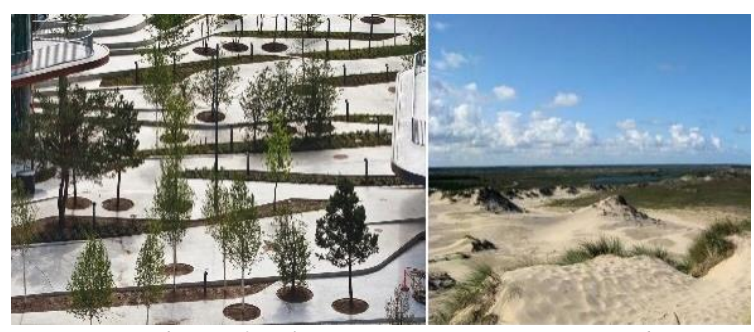

Fig. 7. The artificial terrain appearance compared to a migrating coastal dune in Denmark [Photo $\mathbb{C}$ Left: SLA, Right: Matthias Schalk/Wikimedia Commons]

technical demands, and at the same time endows this urban space with a strong and unique Nordic identity. The rhythms of planting design also echoing the succession habitats. Similar to the previous project (the Green), the design concept is intensive and applied to the whole area of the site, playing a functional role and bringing a sense of identity.

\section{Esplanade Paul Grimault, 2011}

Annecy, France, Plaza,

Designer: Agence APS

Design_ The project adopts a contextual and sensitive approach in an attempt to recreate the story of the esplanade. The project refers to places and experiences known by mountaineers by several means. The triangle of the plant esplanade with its location on a flat terrain and the design vocabulary refers to the geography of limestone "plateau" and the Parmelan lapiaz [10].

Geological Influence_ The lapiaz is called karren in the Earth science. Karren is the group of solution microforms on groopved karstifiable surfaces created by rainwater.

The project uses references to the local mountain environment in a subtle and abstract way, bringing the esplanade back into context with its environment and the native vegetation; while the material was switched to concrete instead of the limestone. The interpretation is two-dimensional and decorative, it is not assigned with other functions that could allow more interaction with the users.

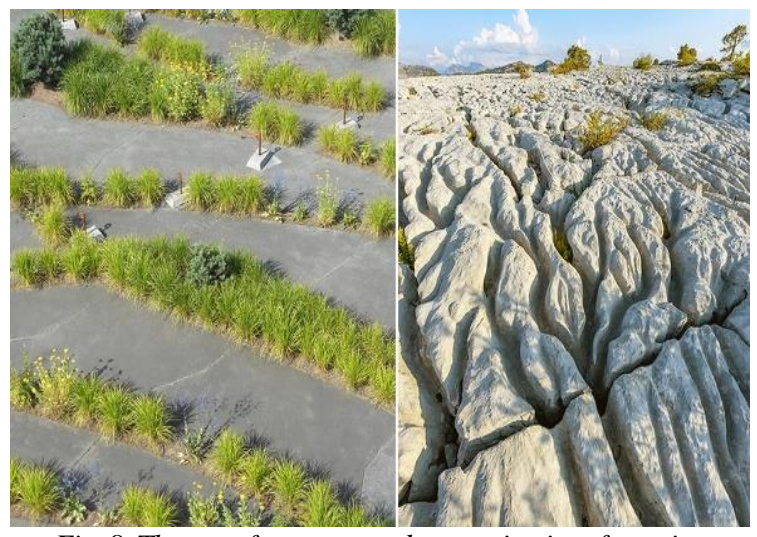

Fig. 8. The use of concrete and vegetation in referencing the grooves of lapiaz in the plaza compared to the actual appearance of lapiaz [Photo $($ Left: Agence APS, Right: Jean Philippe Delobelle] 


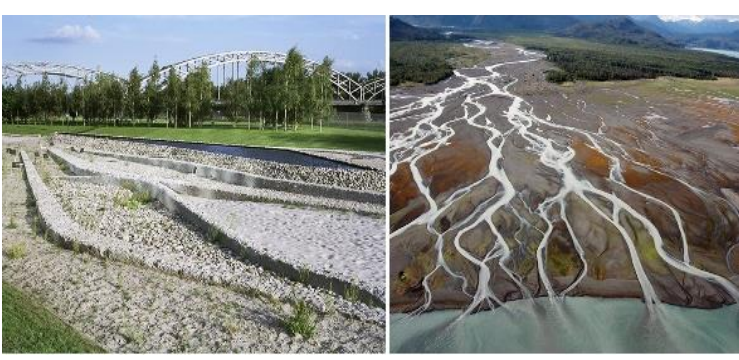

Fig. 9. The simplified geometric forms used in the park compared to the dynamics of alluvial braided streams [Photo $($ Left: Florian Holzherr, Right: worldatlas.com]

\section{ECB Premises - Head Office, 2013}

Frankfurt, Germany, Urban Park

Designer: VOGT Landscape Architects

Design_ The design takes its basic idea from the most powerful feature of the site, the river, by abstracting the typical terrain of natural flood plains. The park is a stylised alluvial landscape with clefts and plateaus, backwaters, undercuts and slopes abstracted to simple geometric forms, creating several zones within the dynamic of the moving terrain. The vegetation also represents the alluvial environment, even though it does not exclusively display native alluvial species. Along with widely spaced indigenous trees, dense woods and natural hedges, many exotic plants can also be found in this designed habitat [8].

Geomorphological Influence_ The alluvial streams are those which flow on their own alluvium (= material deposited by rivers).

The reference to the alluvial landscape with a sense of perplexity and the use of clear geometric lines and shapes, and various size, color of gravels like sediments, allow the park to ease the transition between the buildings of the site and the river. The interpretation of this geomorphological influence is intensive and attempts to present a complex habitat with materials, plants and forms even though those forms are simplified and abstracted.

\section{Metamorphous, 2015}

Vancouver, B.C, Canada, Wall Sculpture

Designer: Paul Sangha Landscape Arch.

Design_ The project aims to enhance the foreshore and deal with the retention of the bank. In addition to strategic boulder placement along the foreshore, which facilitates creating habitat for flora and fauna, the design includes a corten steel retaining wall, created as an abstraction of sandstone formations seen on Saturna Island in British Colombia [11].

Geomorphological Influence_Sandstone belongs to the group of clasolite sedimentary rocks, built up of sand grain and bonding. Most typically, the sand grains can be silica sand, the binding can be silicic acid, calcite or clay. Colour and strength of rock depends on binding.

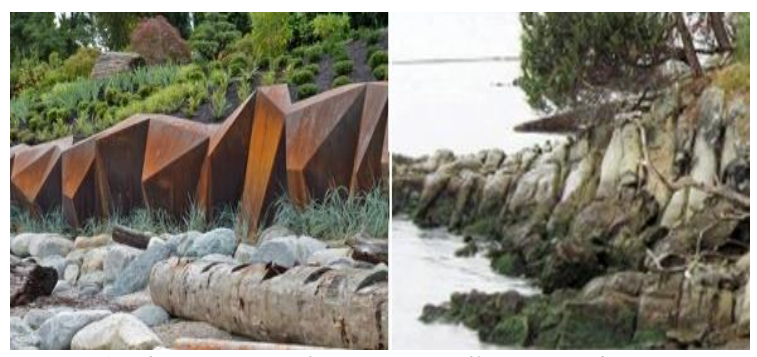

Fig. 10. The corten steel retaining wall compared to Saturna Island sandstone formations [Photo $(\mathrm{C}$ Left: Tim Swanky, Right: Paul Sangha Landscape Architecture]

The abstract form of the wall is both functional and artistic, that besides performing as a retaining wall is also is helping to sculpt an identity for Vancouver's shorelines.

\section{Barangaroo Reserve, 2015}

Sydney, NSW, Australia

Landscape - urban

Designer: Johnson Pilton Walker/ PWP

Design_ The new harbor foreshore park was intended to provide new contemporary functions. Water-jetted blocks of sandstone, quarried on the site, a material that references both the topography and the building material of early Sydney, were used to form the foreshores and accommodate functions. The sandstone bedding was set north-east to south-west mimicing natural tessellated pavement, with the weathering patterns found on Sydney's exposed sandstone escarpments [12].

Geomorphological Influence_

Tessellated pavement consists of relatively flat rock surfaces, typically the tops of sandstone beds and other sedimentary rocks, which are subdivided into regular rectangles or blocks approaching rectangles by systematic orthogonal joint systems. The sandstones can be classified by grain size and level of cohesion. Coarse-grained sandstone is built up of sandgrains with a diameter of 2-0.05 mm.

The resulting configuration mimics a natural formation in a stylised way, integrating contemporary functions with cultural references and natural processes, which adds enormously to the overall quality of the park's design.

The interpretation of the geological phenomenon in the design is quite intensive, applied on the entire shoreline around the park and is assigned with functions, which makes it a main feature in the park.

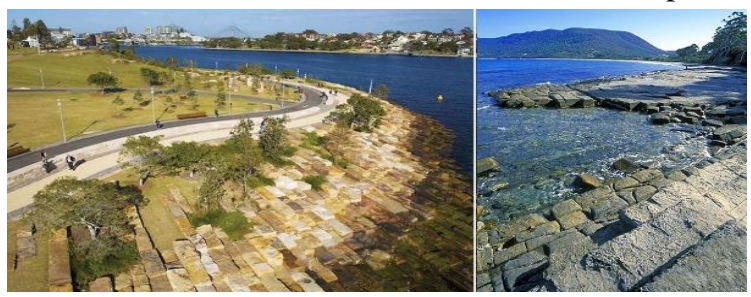

Fig. 11. The new harbor foreshore compared to natural tessellated pavements in Australia) [Photo $@$ Left: Barangaroo Delivery Authority, Right: robertharding.com 83-12018] 

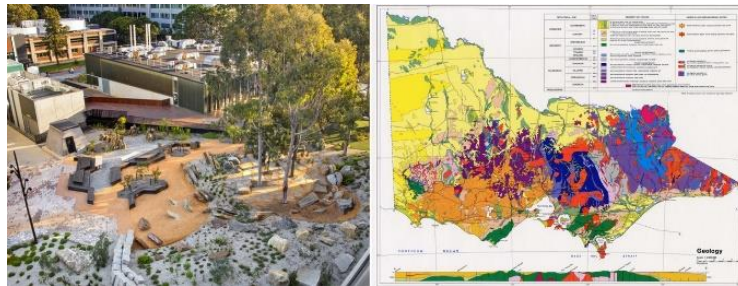

Fig. 12. The display of the rocks in the garden compared to the geological map of Victoria in 1982 [Photo (C) Left: John

Gollings, Right: earthresources.vic.gov.au MP-M-42127]

Earth Sciences Garden - Monash University, 2016

Clayton, Australia, Garden

Designer: Rush Wright Associates

Design_ The design is a new form of system garden. It is an outdoor teaching laboratory that displays key features of the geology and geomorphology of Victoria. The garden displays 20 different types of rocks, which were selected by tracing the shapes and forms of Victoria's geological and geographical features. Plantings also echo the environment of specific Victorian regions. All components are specifically arranged so that students may map and understand the fundamental geological and geomorphological processes of Victoria [13].

Geological Influence_ The geological history of Victoria dates back to one billion years ago. The variety of this rich history appears in several geographical regions, such as the rocky Gippsland and Otway coasts, the western volcanic plains, the sandy dune fields of Wimmera Mallee, the bend of Yarra River, and the outline of Lake Tali Karng.

The garden echoes complex environments of different regions of Victoria in an interesting way. Although the geological interpretation contributes mainly to an educational function, it was applied in a way that integrates geological science with landscape architecture and art, creating a place to be enjoyed by everyone, not only students.

\section{L'enfance du pli, 2017}

Meyrin, Geneva, Switzerland

Park - Playground, Designer: Gilles Brusset

Design_ The Fold's childhood is an interpretation of the force that spawned the folded and undulating landscapes of the Jura massif. Meeting of two formal systems: the orthogonal landscape of Meyrin Park and the nearby flat facades of the École des Boudines, the sculpted landscape emerges with dynamic undulation of the ground creating a unique space for children. The design is simple and clear, the grass reminds us of the Jura pastures [14].

Geomorphological Influence_ The Jura is a part of the Alpine foreland. Toward the northeast and along the outer ridges of the arc, the elevations of the crests are lower. The main thrust of the deformation process occurred from the southeast during the Pliocene Epoch. The mountain-building process took place in two thrust phases: the first one formed the outer, French chain of ridges, and the

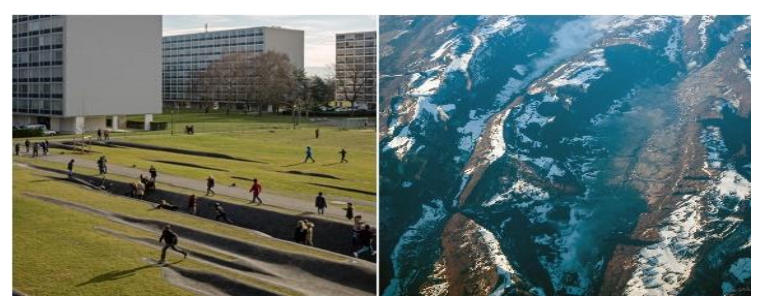

Fig. 13. The spatial structure of the park compared to the ridges and valleys of the Jura Massif [Photo $(\mathrm{C}$ Left: Pierre-Yves Brunaud, Right: C Pelan]

second thrust formed the adjacent, higher inner ranges. Pastures on the high plateaus are more characteristic to the Jura than are the cultivated fields in the basins and valleys.

The project's mimicry appears in curves and volumes, providing children a physical experience of a distinctive spatial structure. This interpretation is the main feature of the site and assigned with function, which gives it a strong dominant effect on both the use and the perception of the space.

\section{Summer Island - The undulating landscape from the data matrix, 2019}

Heilbronn, Germany, Public Landscape Park

Designer: LOMA

Design_ The park is one of the world's first digitally-designed and built parks. The design presents organically shaped terrain-waves joined up diagonally at an angle to imitate a sandy landscape and its ephemeral patterns, natural shapes of dunes and moraines. There is neither an entrance nor an exit, no paths and no benches, since the green dunes divide the space and serve these functions [15].

Geomorphological Influence Two similar types of forms are described by geomorphology. 1: Sand waves are created at the bottom of the bed by the process of traction load. 2: Ripple-marks are created by wind and their forms are parallel with each other.

The design inspiration was drawn from a general phenomenon, not related to the local environment of the site, and was applied quite intensively to the whole area of the site, The result of this imitation of a sandy landscape is a 'walkable sculpture', a green sea of waves for people to sit, climb, sunbathe or joyfully roll around.

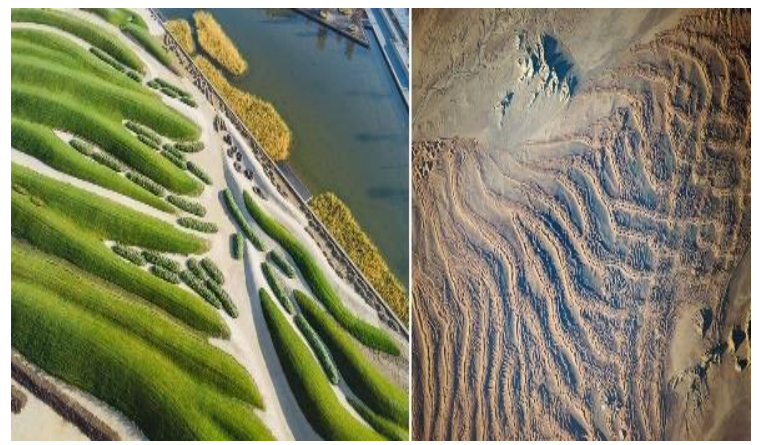

Fig. 14. The organically shaped terrain-waves of the park compared to linear dunes of an erg [Photo $\mathbb{C}$ Left:

Nikolai Benner, Right: nasa.gov ID- ISSO47-E-23405] 


\section{The aspects of projects comparison (Figure 15)}

After collecting and describing the listed projects, a concise comparative sheet has been prepared to conclude the design tendencies of nowadays. The structure of the comparison is based on pairs of contrasting qualities in the form of semantic differential scales. The projects are identified with numbers (1-12) that are placed on the bar.

Defining the counterpart-qualities / comparison aspects:

- Decorative / Functional $=$ this pair describes whether the design has only a decorative, ornamental approach (nice pattern, form), or it rather fulfills functional aims, such as educational purposes, displaying plants or designating parts of it for sport activities, play or leisure.

- Local / General = this pair compares the geological origin, whether the applied formation originates from a close-by, site-specific landscape which gives the site a sense of local identity; or the design refers to a more common, universal geological pattern.

- Areal 2D / Spatial 3D = this aspect refers to the spatial qualities, whether the design translates the geomorphological origins into patterns or pavements, or applies it as a sculptural form of volumes and spatial experiences.

- Moderate / Intensive $=$ this pair relates to the previous one, while the moderate design appears with limits, on a part of the area; the intensive design takes over the site, so that the whole character of the site is mainly influenced by the geological reference.

- Geology / Complex Habitat $=$ this aspect seeks to distinguish if the design takes only the natural rock as a source of influence, or it has a wider context: including local vegetation or landscape patterns as well.

The comparison chart (Fig. 15) presents the authors critic of the projects in accordance with the chosen pairs of qualities.

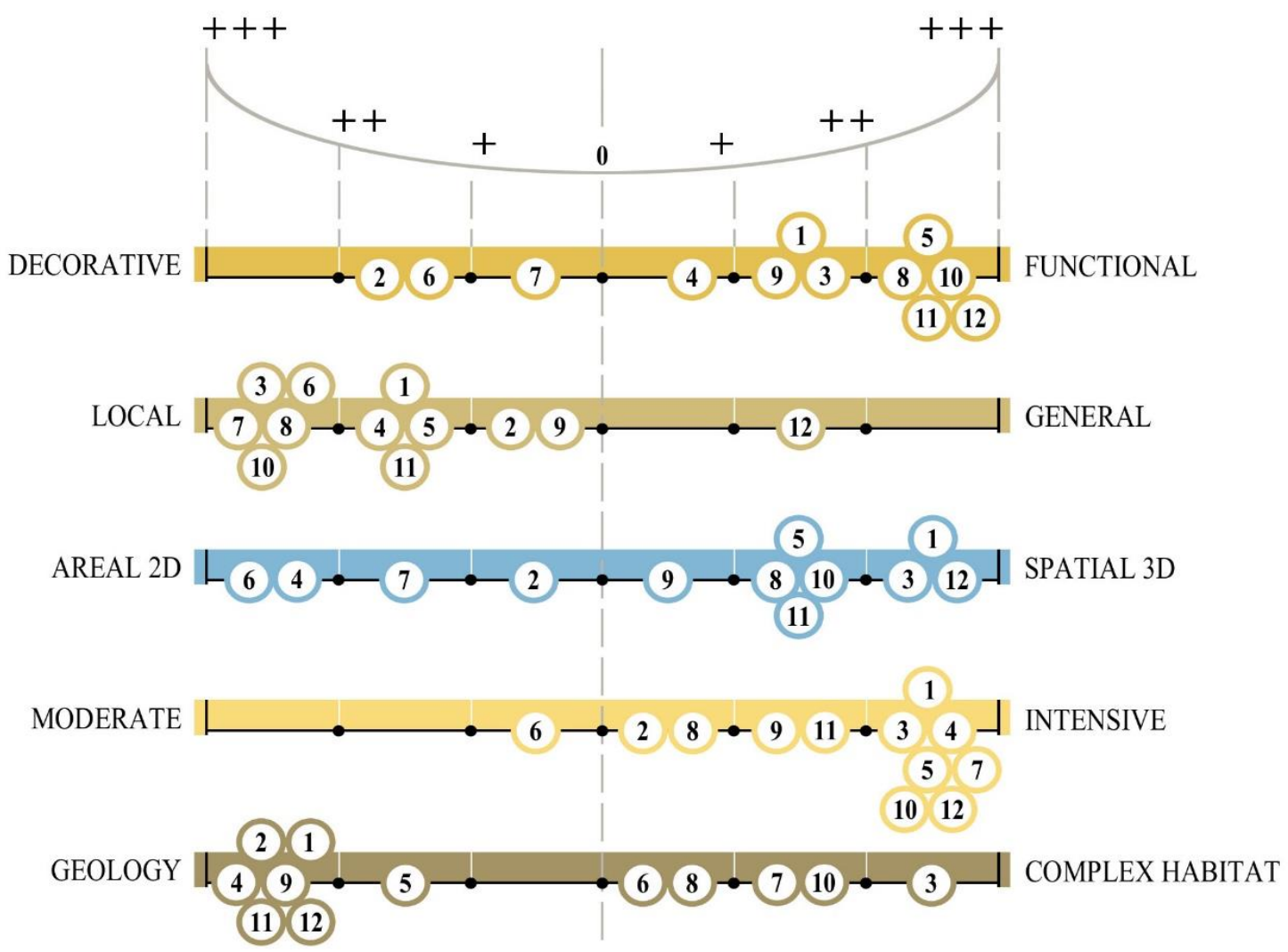

1. Federal Courthouse Plaza

2. Interpolis Headquarters Garden

3. Teardrop Park

4. The Green

5. The City Dune - SEB Bank

6. Esplanade Paul Grimault
7.ECB Premises - Head Office

8. Metamorphous

9. Barangaroo Reserve

10. Earth Sciences Garden

11. L'enfance du pli

12. Summer Island - The undulating

landscape from the data matrix

Fig. 15. A comparative chart of the 12 analysed projects [created by the author] 


\section{Results and Conclusions}

The chart demonstrates some common tendencies regarding geologically influenced contemporary designs:

- The last 15 years were especially rich of urban design projects imitating and mimicking geology in very different ways. It is assumed, that contemporary open-air design do use this elementary, background layer of natural feature.

- Most of the projects tend to utilise their geological interpretations and assign functions to the features even if they contribute merely to the division of the space or the orientation of movement.

- Most of the references are strongly related to local or regional natural features that are very well-known and familiar in the collective memory of the local users. It is assumed, that providing an emotional impact for the users would strengthen the spatial identity and spatial attachment.

Both, 2D patterns and 3D formations of geological features are inspirational sources for contemporary designs. However, the designs that adopted a 3D approach showed more complexity, and were able to have not only decorative roles, but also to provide functions, allowing for a better interaction and contributed more effectively to the experience of space.

The geological influence determines all other elements contributing to the design. It is expressed clearly and explicitly. Whether the interpretation is applied on the whole site or on a limited section, and whether it is an artistic abstraction or an exact duplicate, the geological influence remains the main factor that defines the spatial experience.

Most of the projects tend to focus on a single natural feature and communicate it with a clear visual appearance rather than including all the associated features within the bigger complex habitat.

To sum up, we can state that, contrary to the mentioned historical approaches, which mainly relied on copying real sites and creating duplicates of existing nature, the contemporary design approach tends to prefer abstraction of natural features. References and interpretations are more artistic: conceptual, delicate or sometimes even unnoticeable. Design takes inspiration from the textures, colors, structure, patterns, native vegetation or volumes of a geological phenomenon, rather than duplicating the exact phenomenon. This tendency started in the middle of the $20^{\text {th }}$ century, but in the last two decades, it started having more of a design appearance, underlining the message that landscape architecture should be based on geology again!

On another hand, this contemporary approach can play a balancing role as a response to one of the main phenomena of this age, globalization. As globalization processes are exposing most parts of the world to similar influences, people start feeling insecure as their cultural underpinning weakens [2]. This cultural insecurity leads people to look for recognizable points of reference in their own surroundings, and the contemporary design approach is keen to providing these local references, a task made only easier by relying on the principle of drawing inspiration from the geology of the local area.

To sum up, we can state that, contrary to the mentioned historical approaches, which mainly relied on copying real sites and creating duplicates of existing nature, the contemporary design approach tends to prefer abstraction of natural features. References and interpretations are more artistic: conceptual, delicate or sometimes even unnoticeable. Design takes inspiration from the textures, colors, structure, patterns, native vegetation or volumes of a geological phenomenon, rather than duplicating the exact phenomenon. This tendency started in the middle of the $20^{\text {th }}$ century, but in the last two decades, it started having more of a design appearance, underlining the message that landscape architecture should be based on geology again!

On another hand, this contemporary approach can play a balancing role as a response to one of the main phenomena of this age, globalization. As globalization processes are exposing most parts of the world to similar influences, people start feeling insecure as their cultural underpinning weakens [2]. This cultural insecurity leads people to look for recognizable points of reference in their own surroundings, and the contemporary design approach is keen to providing these local references, a task made only easier by relying on the principle of drawing inspiration from the geology of the local area.

\section{References}

1. Weilacher, Udo. (2005). In Gardens: Profiles of Contemporary European Landscape Architecture: Birkhäuser.

2. Simon, C. J. M. (2005). Ruimte voor identiteit: De productie en reproductie van streekidentiteiten in Nederland: Groningen.

3. Jodidio, Philip. (2012). Landscape Architecture Now!: Taschen GmbH 
4. Isachsen, Y.W, Landing, E, Lauber, J.M, Rickard, L.V, Rogers, W.B. (2000) Geology of New York, A Simplified Account: New York State Museum.

5. Martha Schwartz Partners [online 10.10.2021.]. https://msp.world/minneapolis-courthouse-plaza-minneapolis-mn-usa/

6. West 8 office for urban design and landscape architecture [online 10.10.2021.]. https://www.west8.com/ projects/interpolis_garden/

7. Michael Van Valkenburgh Associates [online 10.10.2021.]. https://www.mvvainc.com/project.php?id=2

8. Vogt Landschaftsarchitekten | Vogt [online 02.12.2021.]. https://www.vogt-la.com/en

9. SLA - Urbanity. Strategy. Landscape [online 10.10.2021.]. https://www.sla.dk/en/projects/city-dune/

10. Agence APS [online 10.10.2021.]. https://www.agenceaps.com/realisations-aps/amenagement-esplanade-grimault-annecy/

11. Paul Sangha Creative [online 10.10.2021.]. https://paulsangha.com/project/metamorphous

12. PWP Landscape Architecture [online 10.10.2021.]. http://www.pwpla.com/projects/barangaroo/\&details

13. Rush Wright Associates [online 10.10.2021.]. http://www.rushwright.com/earth-sciences-garden-monash-university

14. Landscape Architecture Platform | Landezine [online 10.10.2021.]. https://landezine-award.com/folds-childhood-2/

15. LOMA architecture. Landscape, urbanism [online 10.10.2021.]. http://www.loma-online.de/

This article is published within the framework of Hungarian Academy of Arts: Anna Eplényi - Scholar 2018-2021, with the research topic Contemporary terrain modeling - artistic landforming.

AUTHORS:

Nawarah Al Basha, PhD student, Landscape Architecture MA, Institute of Garden Art and Landscape Design, Szent István University, Budapest. A previous tutor at the Faculty of Architecture in Damascus, Syria. She focuses her research on spatial identity, spatial attachment and landscape forms and patterns. E-mail: Albasha.Nawarah@hallgato.uni-szie.hu

Anna Eplényi PhD, Associate lecturer at the Institute of Garden Art and Landscape Design, Szent István University, Budapest. She teaches garden history, freehand drawing and other creative art modules. She focuses her research within the framework of Hungarian Academy of Arts on contemporary, artistic terrain modelling. E-mail: eplenyi.anna@tajk.szie.hu

Gábor Sándor, assistant lecturer at the Department of Landscape Protection and Reclamation, Szent István University, Budapest. He teaches Hungary's landscape geography, soil investigation on fieldwork and other landscape architecture-related modules. He focuses his research on geological values, urban soil and soil classification. E-mail: sandor.gabor@tajk.szie.hu

Kopsavilkums. Pētījums veikts par divpadsmit pieejamiem, mūsdienās publicētiem ainavu projektiem pēdējās divās desmitgadēs, izvērtējot dabas imitāciju caur fotofiksācijām, dokumentiem un aprakstiem. Analizētie projekti savstarpēji salīdzināti pēc vienotām kvalitātēm, izmēriem, telpas raksturlielumiem, kas l̦āvis noteikt dažādas mūsdienu ainavu arhitektūras kopīgās tendences, nodefinējot atbilstošas dizaina pieejas ainavtelpas izveidē. 